\title{
CALLUS INDUCTION AND PLANTLET REGENERATION ABILITY OF SE- LECTED SRI LANKAN TRADITIONAL RICE CULTIVARS (ORYZA SATIVA L.) IN CARYOPSES CULTURE
}

\author{
N Dahanayake*, AL Ranawake \\ Department of Agricultural Biology, Faculty of Agriculture, University of Ruhuna, Mapalana, Kamburupitiya, \\ Sri Lanka \\ Accepted: $5^{\text {th }}$ January 2011
}

\section{Abstract}

A total of forty Sri Lankan traditional rice varieties (Oryza sativa $\mathrm{L}$ ) were examined for their callus induction, growth and regeneration ability at Laboratory of Agricultural Biology, Faculty of Agriculture, University of Ruhuna. Surface sterilized rice seeds (caryopses) were cultured on four different callus

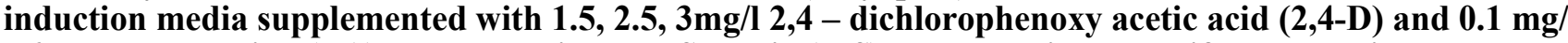
16 - benzyladenine (BA) on Murashige and Skoog's (MS) basal medium. Proliferated calli were regenerated on 4 different regeneration media supplemented with $1.5,2,2.5,3 \mathrm{mg} / \mathrm{l} \mathrm{BA}$ with $0.1 \mathrm{mg} / \mathrm{l} \mathrm{naph}-$ thaleneacetic acid (NAA). Eighty seven point five \% of rice cultivars were able to produce callus on callus induction medium and among them $12.5 \%$ of rice cultivars regenerated shoots. $100 \%$ callus induction was recorded by $75 \%$ of tested rice cultivars on $2.5 \mathrm{mg} / \mathrm{l}$ 2,4-D supplemented to MS basal medium while the callus induction percentages were $30 \%$ and $32.5 \%$ in $1.5 \mathrm{mg} / 1$ 2,4-D and 3mg/l 2,4-D supplemented media respectively.

Callus growth of rice cultivars showed significant difference with the cultivar and medium. By the $4^{\text {th }}$ week of callus induction maximum diameter $(>2 \mathrm{~cm})$ of callus recorded by rice cultivar Herath on 2.5 $\mathrm{mg} / \mathrm{l} 2,4-\mathrm{D}+0.1 \mathrm{mg} / \mathrm{l} \mathrm{BA}+\mathrm{MS}$ basal medium. The regeneration ability of rice cultivars varied from $0 \%$ to $100 \%$ while the highest regeneration was recorded in rice cultivar Herath on regeneration medium supplemented with $2.5 \mathrm{mg} / \mathrm{l}$ BA and $0.1 \mathrm{mg} / \mathrm{l}$ NAA. Callus induction varied from $0 \%-100 \%$ and significantly high callus formation was offered in Dik wee, Herath, Pachchai Perumal and Rathu wee. Sudu bala wee, Kahata wee (long grain), Sudu heenati, Kahata samba and Muthumala failed to initiate callus on any of the medium. Significantly highest shoot regeneration percentage was found in Herath (100\%) while Mas samba, Seedevi, Dostara heenati and Rathel were also categorized in to the same DMRT (Duncan's Multiple Range Test) group with Herath. The highest number of shoots (8 shoots/callus) was recorded in Herath compared to other varieties (0.1- 8 per explant). There was a significant interaction between callus induction medium and rice cultivar as well as regeneration medium and rice cultivar.

Key words: Oryza sativa L. Traditional rice, Callus, Regeneration

\section{INTRODUCTION}

Rice is a cereal crop that belongs to family Poaceae and is of tremendous economic importance. It is a staple food for a large human population in the world. It is feared that world population would be around 10 billion by 2050. Thus more food will be required to feed the human population. This will be in the backdrop of diminishing cultivated land. Studies are underway to increase yield as well as quality of rice.

Sri Lanka is considered as a valuable repository of crop germplasm and agro-biodiversity. It has a rich treasure of rice genes and over 2,800 varieties have been recorded in the coun-

\footnotetext{
*Corresponding author: nilanthi@agbio.ruh.ac.lk
}

try. These varieties show great adaptability to a wide range of climatic and soil conditions as well as pest and disease problems. They also exhibit variation in grain size and quality, some with medicinal properties and fragrance and others that are used for cultural and ritual reasons also show differences in maturity period. (http://goviya.com/agro-biodiversity2.htm).

A diet of traditional rice three times a day gave our ancestors all the energy they needed to carry out a multitude of heavy tasks, from ploughing paddy fields to chopping firewood, to walking several miles daily and still have energy to spare. Ailments such as heart attack, high blood pressure or diabetes were almost unheard of. Different historical records re- 
vealed that traditional rice varieties were revered for their nutritional and medicinal properties.

Regeneration from callus was achieved many years ago in Japonica varieties (Nishi et al., 1973). The potential for callus formation and regeneration has been reported to be a varietal characteristic. An efficient callus induction and proliferation followed by regeneration in Indica rice is still poses a major problem for genetic manipulation through innovative approaches (Toki, 1997). While it has been possible to obtain high callus induction, proliferation and plant regeneration frequencies in Japonica rice varieties, the success for reproducible fertile plant regeneration has been limited in Indica rice varieties so far (Kyozuka et al., 1988; Raman et al., 1994). As a result, progress towards the transfer of useful genes into Indica rice has been slow. Many factors have been examined to improve the frequency of callus induction and plant regeneration in rice.

Organogenesis of callus tissues depends upon plant species, type of explant from which the callus was derived, age of callus tissue and composition of the nutritional medium. Another important factor is nature and level of various growth regulators. Although there has been some success in plant regeneration from rice tissue culture, the protocol so developed is not applicable to all the cultivars of rice. Therefore, a suitable method has to be developed for local rice varieties. Forty traditional rice varieties were selected for the present study since they are localized varieties to Sri Lanka and no callus induction and regeneration has been reported earlier.

\section{MATERIALS AND METHODS}

Seeds of forty traditional rice varieties (Oryza sativa L) were collected from Plant Genetic Resource Centre, Ganoruwa, Peradeniya and the experiment was conducted at the laboratory of Department of Agricultural Biology, Faculty of Agriculture, University of Ruhuna in 2011.

Surface sterilization of seeds were done by dipping seeds in $70 \%$ Ethyl alcohol for 2 minutes followed by $10 \%$ Chlorex solution for $30 \mathrm{~min}-$ utes. These seeds were washed out thoroughly several times with autoclaved distilled water.
Seeds were cultured on Murashige Skoog's (1962) basal medium supplemented with 3\% sucrose with different concentrations of 2,4 - D $(1.5,2.5,3.0 \mathrm{mg} / \mathrm{l})$ and $0.1 \mathrm{mg} / \mathrm{l} \mathrm{BA} . \mathrm{pH}$ of the medium was adjusted to 5.6 and solidified with $0.6 \%$ agar. Phyto-hormones were added to the medium before $\mathrm{pH}$ adjustment. The medium was autoclaved at 15 psi for 15 minutes at $120^{\circ} \mathrm{C}$. Experiment was done according to the complete randomized design with 10 replicates and was repeated three times. Sub culturing was done after 2 weeks and repeated two times. Cultures were kept in 16 hours cycled fluorescent light cooled incubators with temperature regulated at $25 \pm 1^{0} \mathrm{C}$.

Proliferated Calli were grouped according to callus diameter; Group 1- $<0.5 \mathrm{~cm}$, Group 2$>0.5-1.0 \mathrm{~cm}$, Group 3- $>1.0-1.5 \mathrm{~cm}$, Group 4- $>1.5-2.0 \mathrm{~cm}$, Group 5. $>2 \mathrm{~cm}$ and Group 6- no callus formation. Calli were transferred to MS based regeneration medium supplemented with different concentrations of BA $(1.5,2.0,2.5,3.0 \mathrm{mg} / \mathrm{l})$ and $0.1 \mathrm{mg} / 1 \mathrm{NAA}$. Number of shoot developed in each culture tube was counted after 30 days in the regeneration medium. Data was analyzed by Student Newman-Kuells Means Separation Test of SAS (SAS Institute, Cary, NC, 1995).

\section{RESULTS AND DISCUSSION}

There was a significant difference in callus induction ability of traditional rice cultivars in different callus induction media (Fig. 1A and B). By the second week of culturing rice cultivars Dik wee, Herath, Pachchai Perumal and Muthumala initiated callus induction while $K o$ lokuttu, Yakada wee, Polayal, Sivuru wee and Manamalaya started callus induction within 4 weeks . Among these varieties significantly highest callus induction was recorded on MS medium supplemented with $2.5, \mathrm{mg} / 1$ 2,4 -D regardless of rice cultivars. Rice cultivars $S u d u$ bala wee, Kahata wee (long grain), Sudu heenati, Kahata samba and Muthumala were unable to produce calli on any of the medium.

Among callus producing cultivars the highest callus induction percentage $(87.5 \%)$ was recorded by Herath on MS + 2.5 mg/1 2,4 - D of the selected traditional rice varieties maximum callus formation was observed in Dik wee, Herath, Pachchai Perumal and Muthumala and 

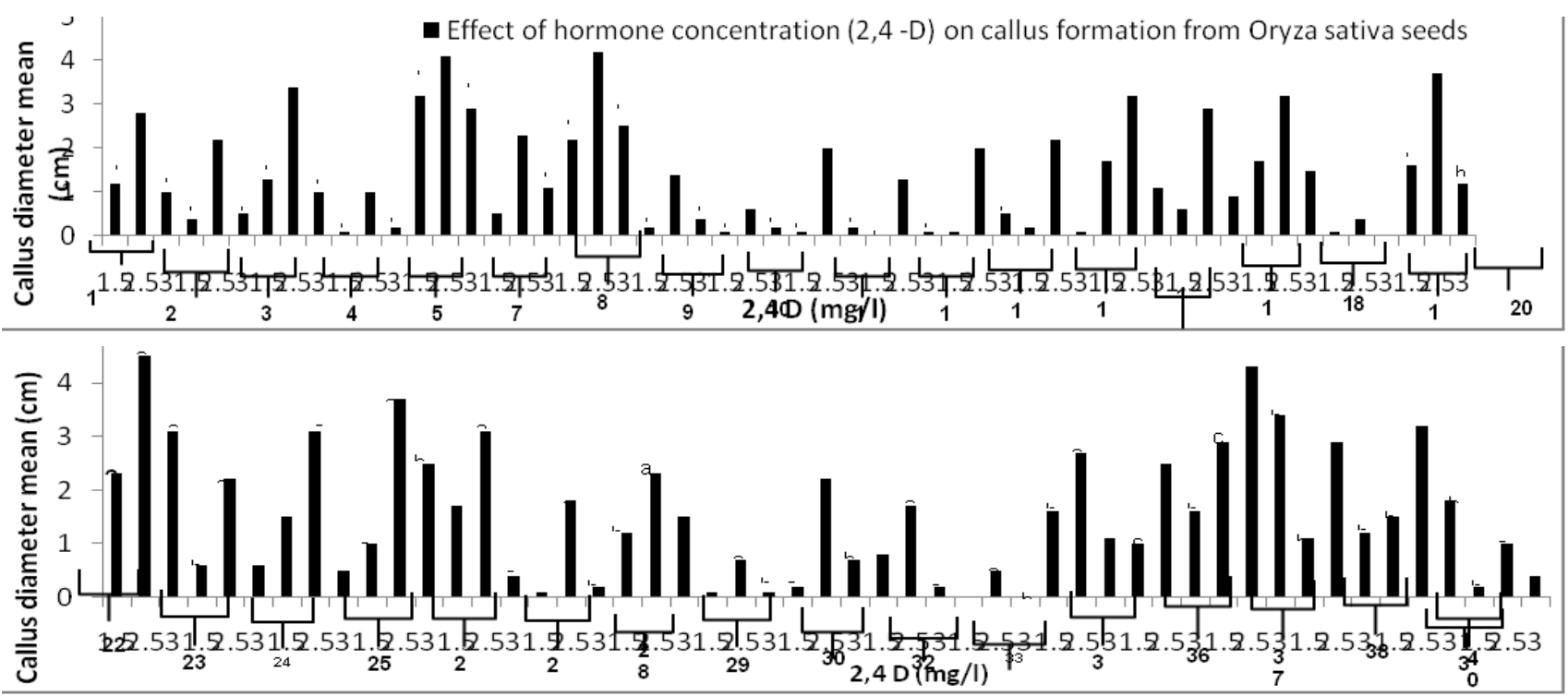

Fig. 1: Effects of different concentrations of 2, 4-D on the formation of callus from seeds of 40 traditional Oryza sativa varieties

There is a significant difference on initiation of callus from Oryza sativa traditional varieties at $(\mathrm{P}<0.05)$ level. Means fallowed by the same lower case letters in each bar are not significantly different at 5\% level in Duncan's Multiple Range Test.

1. Suduru samba 2. Weda Heenati 3. Randunipagal 4. Polayal 5. Pachchai Perumal 6. Sudhu bala wee 7. Kalubala wee 8. Dik wee 9. Masuran 10. Sivuru wee 11. Kalukantha 12. Pokkali 13. Sudu heenati 14. Ruwanrathran 15. Kahata wee (long grain) 16. Mudaliwi 17. Handiran 18. Gonabaru 19. Kolikuttu 20. Rathu heenati 21. Heenati 309 22. Herath 23. Rathkara 24. Mas samba 25. Seedevi 26. Dostara heenati 27. Rathel 28. Tharalu 29. Manamalaya 30. Kottamalli 31. Kahata samba 32. Sudu wee 33. Yakada wee 34. Danahala 35. Muthumala 36. Molaga samba G-18 37. Rathu wee 38. Kiri naran 39. Sudu hatada 40. Nadu heenati

these were the cultivars responded early for callus induction.

Callus induction as well as regeneration potential was affected not only by genotype and the type of explant but also by composition of the culture medium including plant growth regulators, and by culture conditions. This is in agreement with Rueb et al. 1994 who have reported that particular genotype and type of explant are important factors for the successful embryogenic callus induction and regeneration of rice plants.

The highest regeneration percentage $(100 \%)$ was recorded by Herath on regeneration medium supplemented with $2.5 \mathrm{mg} / \mathrm{ml} \mathrm{BA}$ and 0.1 $\mathrm{mg} / \mathrm{ml}$ NAA and this was the rice cultivar which recorded the earliest callus induction and greatest callus proliferation $(100 \%)$ but there was no positive relationship between time to take for callus initiation or callus proliferation ability with regeneration.

Among tested regeneration media significantly high regeneration was recorded on MS basal medium supplemented with $2.5 \mathrm{mg} / 1$ BA re- gardless of rice cultivar. There was no relationship between the callus induction medium and regeneration medium. Though Herath recorded the highest callus production and regeneration percentage among all the tested rice cultivar, other rice cultivars that recorded higher callus proliferation in callus induction medium recorded lower regenerated plantlets in the tested regeneration media.

The successful application of plant tissue culture techniques for crop improvement requires suitable plant regeneration methods. In rice, there are many reports on successful plant regeneration from calli derived from different explants (Nishi et al. 1973; Yamada et al. 1967a, b; Furuhashi and Yatazawa 1964), including inflorescences (Kavikishore and Reddy, 1985). However, the use of tissue culture to propagate traditional rice in Sri Lanka is limited, since regeneration can be obtained only in a limited number of selected traditional rice varieties. This communication summarizes among 40 traditional rice cultivars tested, plantlet regeneration was observed in Herath, Mas samba, Seedevi, Dostara heenati, Rathel, Suduru Samba. 


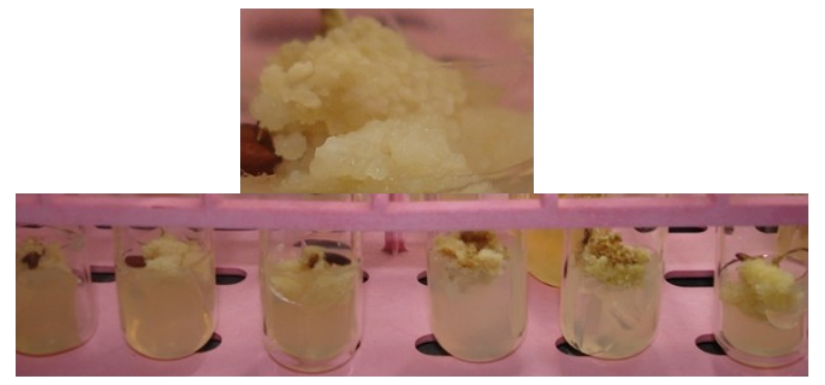

Fig. 2: Callus formation of rice cultivar Herath after four weeks on MS basal medium supplemented with on $2.5 \mathrm{mg} / \mathrm{l} \mathrm{2,4-D} \mathrm{+} \mathrm{0.1} \mathrm{mg/l} \mathrm{BA}$

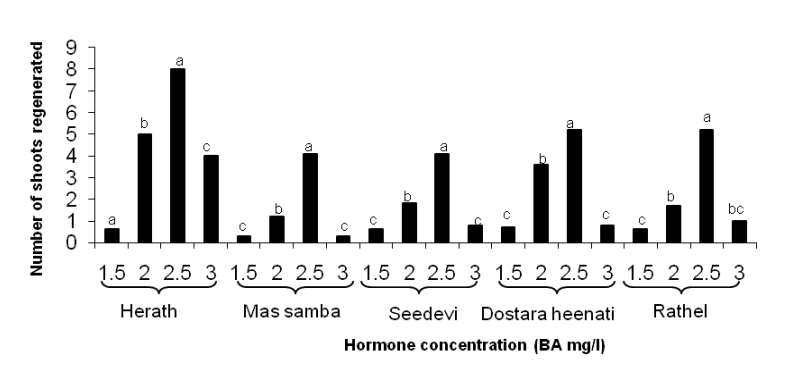

Fig. 3: Effects of different concentrations of BA hormone on regeneration of callus into plantlets

There is a significant difference between callus production and traditional rice cultivar at $(\mathrm{P}<0.05)$ level. Means fallowed by the same lower case letters in each bar are not significantly different at $5 \%$ level in Duncan's Multiple Range Test.

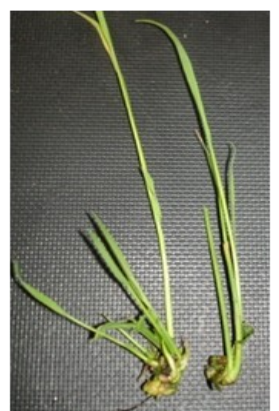

Fig. 4: Regeneration of Sudu samba on MS basal medium supplemented with $2.5 \mathrm{mg} / \mathrm{l} \mathrm{BA}$ and $0.1 \mathrm{mg} / \mathrm{l}$ NAA

\section{CONCLUSION}

Application of of $2,4-\mathrm{D}$ at to the basal callus induction medium significantly increased callus initiation as well as callus proliferation of rice regardless of the cultivar. Other concentrations of 2,4 -D in MS basal medium acted differently on rice cultivars for callus proliferation.

In future studies, $2 \mathrm{mg} / 1$ 2,4-D supplemented to the MS basal medium with $0.1 \mathrm{mg} / \mathrm{ml} \mathrm{BA}$ can be recommended for most of the rice cultivar for highest callus proliferation and the MS based regeneration medium supplemented with $2.5 \mathrm{mg} / 1 \mathrm{BA}$ and $0.1 \mathrm{mg} / 1 \mathrm{NAA}$ as regeneration medium. However but the best combination of callus induction and regeneration media is yet to be found for rice cultivars as the regeneration from callus induction medium was not elaborated in this study.

\section{REFERENCES}

Abe T and Y. Futsuhara 1985 Efficient plant regeneration by somatic embryogenesis from root callus tissue of rice (Oryza sativa L.) Plant Physiol. 121: 111- 118

Chen T, Lau L and Chen S 1995 Somatic embryogenesis and plant regeneration from cultured young inflorescences of Oryza sativa L. Plant Cell, Tissue and organ culture, 4: $51-54$

Furuhashi K and Yatazuva M 1964 Indefinite culture of rice stem node callus. Kagaku 34: 623.

Reddy GM and Coe EH 1986 Oxford Jr.and Publ IBH 1986. New Delhi, India, p. 253-255.

Hahi I 2000 Stress induction in embryo raised wheat germplasm. Project Report, University of Peshawar.

Kavikishor PB and Reddy GM 1986 Regeneration from long term cultures and selection of useful mutants in rice. In: Gene structure and function in higher plants (ed).

Nishi T, Yamada Y and Takahashi E 1968 Organ redifferentiation and plant restoration in rice callus. Nature 219: 508-509.

Rueb S, Leneman M, Schilperoort RA and Hensgens LAM 1994 Efficient plant regeneration through somatic embryogenesis from callus induced on mature rice embryos (Oryza sativa L.). Plant Cell Tiss. Org. Cult. $36: 259-264$.

Wernicke W, Brettell R, Wakizuka T and Potrykus I 1981 Adventitious embryoid and root formation from rice leaves Z. Pflanzenphysiol., 103: $361-365$

Wang MS, Zapaa FJ and De Castro DC 1987 Plant regeneration through somatic embryogenesis from mature seed young inflorescence of wild rice (Oryza perennis). Plant Cell Report, 6: 294 296

Yamada Y, Yanng ZQ and Tang DT 1986 Plant regeneration from protoplast derived callus of rice. Plant cell Report, 5: 85- 88

Yamada Y, Nishi T, Yasuda T and Takahashi E 1967 The sterile culture of rice cells Oryza sativa L. and its application. In: Advances in germ free research and gnotobiology (eds) Miyakawa, M, Luckey TD, Cleashand CRCPress, 337-386. 